\title{
Effect of drainage and saturation on undrained shear strength for compacted sandy soils
}

\author{
Yukio Nakata*,1, Tetsuya Tashita $^{1}$, Hiromu Chibana $^{1}$ and Kenji Matsukata ${ }^{2}$ \\ ${ }^{1}$ Yamaguchi University, Department of Civil \& Environmental Engineering, Ube Yamaguchi, Japan \\ ${ }^{2}$ NEXCO West Nippon Consultants Co., Hiroshima, Japan
}

\begin{abstract}
Collapses of embankments have occurred due to heavy rainfall. It is very important to understand the strength properties under various unsaturated, partially saturated and fully saturated conditions of compacted materials. So, a series of unsaturated and saturated triaxial compression tests for compacted soils have been conducted to understand the effects of drainage and saturation on undrained strength. Soil samples were collected from several road embankments to carry out the experiments. The undrained (CU) strength of compacted material decreased with increase in the degree of saturation. Especially, the strength decreased from partially saturated condition to fully saturated condition was remarkable. The decrease of the materials with volume contractive behaviour was appeared clearly.
\end{abstract}

\section{INTRODUCTION}

Collapses of embankments have occurred due to heavy rainfall. On September 7, 2005, the rain by a typhoon brought an embankment collapse of expressway in Iwakuni of Yamaguchi [4]. It was $520 \mathrm{~mm}$ of accumulative precipitation, and $64 \mathrm{~mm}$ of maximum hourly precipitation. The collapse occurred at $0: 50$ on September 7 at which was the last stage of the heavy rain with $505 \mathrm{~mm}$ of accumulation rainfall. On July 5-8, 2018, a collapse of expressway embankment by a rain occurred in Kure of Hiroshima. The rainfall of $530 \mathrm{~mm}$ of accumulation precipitation and $65 \mathrm{~mm}$ of the maximum hourly precipitation was recorded. Major rain stopped at 7:00 on July 7. The collapse occurred at 8:00 on July 8, so that was 25 hours after the end of major rain. In these events, permeation of rain water and rise of the ground water level was the major cause of collapse. On the other hand, we could not explain the time progression to collapse, such as a difference of the time zone of collapse occurrence.

It is well known in the stability of embankment that the influence of water is the most important. The embankment is constructed by compaction method for the soil with an optimum wet condition. Rainfall water may cause the shifting from unsaturated to saturated condition. Then the compacted material becomes instable. So, it is very important to understand the strength properties under various unsaturated, partially saturated and fully saturated conditions of compacted materials. But there are few research results only of undrained shear behaviour for compacted materials [6], although there are many results for cyclic behaviour $[2,3,5]$.
In this research, a series of unsaturated and saturated triaxial compression tests for compacted soils has been conducted to understand the effects of drainage and saturation conditions on undrained strength. Soils tested were sampled from several road embankments. The experiments were conducted for the specimens which are compacted under in-situ density conditions. The tests have two aims. The first aim is to understand the effect of three drainage conditions under shear process. The three drainage conditions are drained air and water (DADW) condition, undrained air and water (UAUW) condition and drained air and undrained water (DAUW) condition. The second aim is to provide the effects of the saturation conditions on undrained shear (CU) strength. Especially the low suction condition at in-situ embankment materials will be represented to applying compacted specimens.

\section{Unsaturated triaxial compression tests}

\subsection{Material}

\subsubsection{In-situ monitoring}

The monitoring has been performed about suction and degree of saturation at the depth of $0.5 \mathrm{~m}, 1.0 \mathrm{~m}$ and $2.0 \mathrm{~m}$ from ground surface. Moreover, measurement of the groundwater level and rainfall precipitation at the same point were conducted. Fig. 1 shows monitoring result at in-site of expressway embankment. The result was the record in May to August 2018 including rainy season. The rise of the groundwater level was recorded on June 20,29 and July 5 . Highest water level was $1.92 \mathrm{~m}$ on July

\footnotetext{
* Corresponding author: nakata@yamaguchi-u.ac.jp
} 
7. The suction at every depth responded sensitively for every rain. The degree of saturation in the depth of $0.5 \mathrm{~m}$ responded also for every rain. The saturation degree at depth of $1 \mathrm{~m}$ and $2 \mathrm{~m}$ hardly changed. This indicates that it takes a certain period until the inside of the embankment reaches an equilibrium condition in saturation.
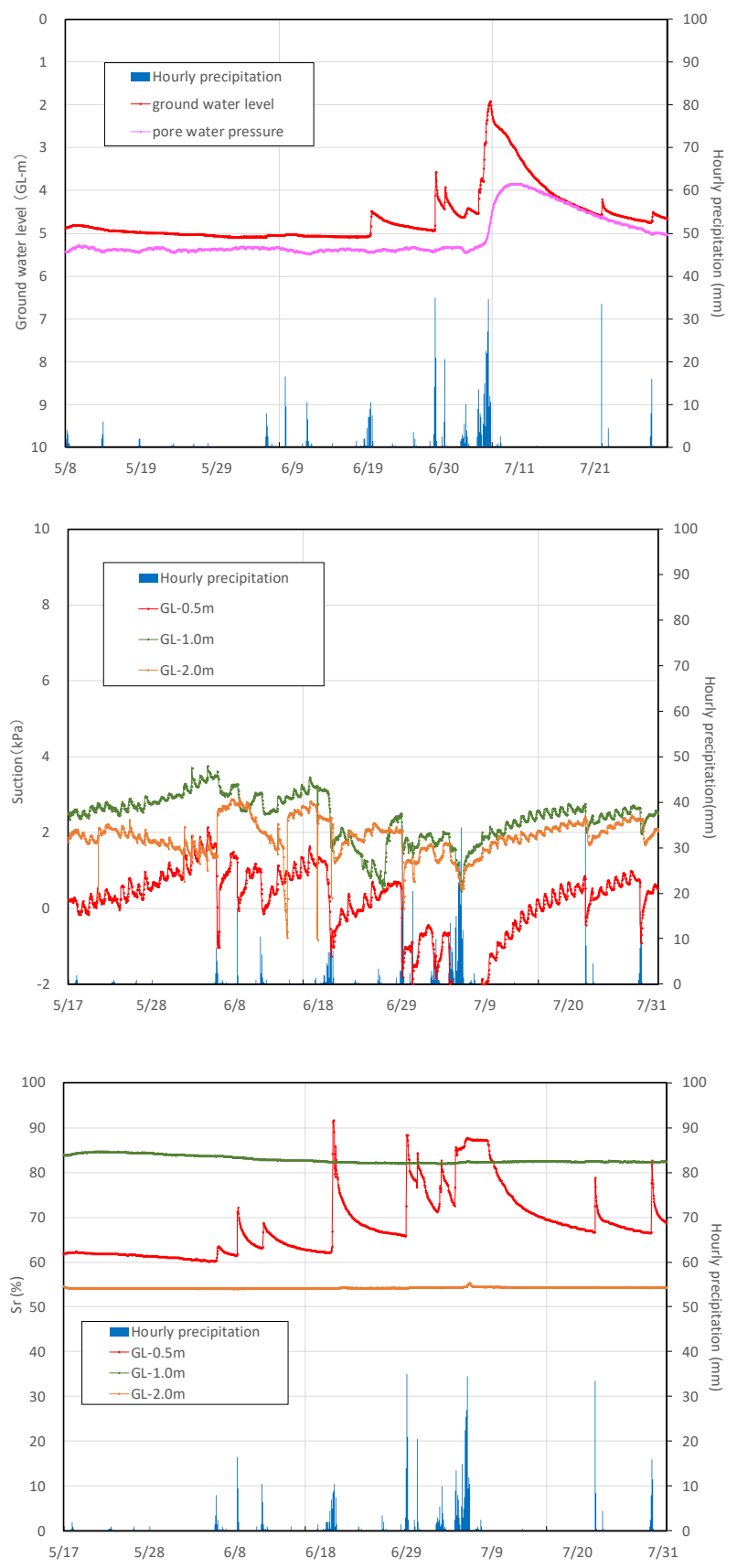

Fig. 1. Time history for ground water level, suction and saturation degree relations of $\mathrm{H}$ material at in-situ condition.

\subsubsection{Physical properties}

The result of the physical tests sampled from five embankments is shown in table 1 . The dry density of the extracted ground was $1.6 \mathrm{~g} / \mathrm{cm}^{3}$. Natural water content was about $16 \%$ to $17 \%$. The degree of saturation was about $67 \%$. The particle size distribution curves are shown in Fig. 2. The fine contents were about 20\%. Figure 3 shows the water characteristic curves for A and $\mathrm{H}$ sample obtained from soil column method. The suction for wetting process is lower than $10 \mathrm{kPa}$.

Table 1. Physical properties of embankment materials

\begin{tabular}{|c|c|c|c|c|c|}
\hline & $\begin{array}{c}\rho_{\mathrm{d}} \\
\left(\mathrm{g} / \mathrm{cm}^{3}\right)\end{array}$ & $\rho_{\mathrm{s}}\left(\mathrm{g} / \mathrm{cm}^{3}\right)$ & $\begin{array}{c}\mathrm{W} \\
(\%)\end{array}$ & $\begin{array}{c}\mathrm{Sr} \\
(\%)\end{array}$ & $\begin{array}{c}\mathrm{Fc} \\
(\%)\end{array}$ \\
\hline $\mathrm{A}$ & 1.63 & 2.65 & 16 & 67 & 20 \\
\hline $\mathrm{H}$ & 1.588 & 2.687 & 17.2 & 66.8 & 18.7 \\
\hline $\mathrm{I}$ & 1.64 & & 15.2 & & $\begin{array}{c}14- \\
40\end{array}$ \\
\hline $\mathrm{K}$ & & 2.653 & - & & 5.8 \\
\hline $\mathrm{M}$ & 1.672 & 2.707 & 20.9 & 91.4 & 27.3 \\
\hline
\end{tabular}

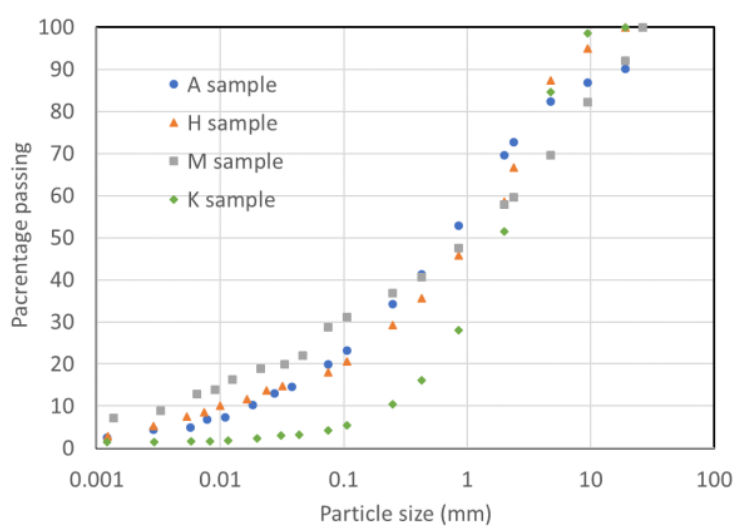

Fig. 2. Particle size distribution A, H, M, K samples.

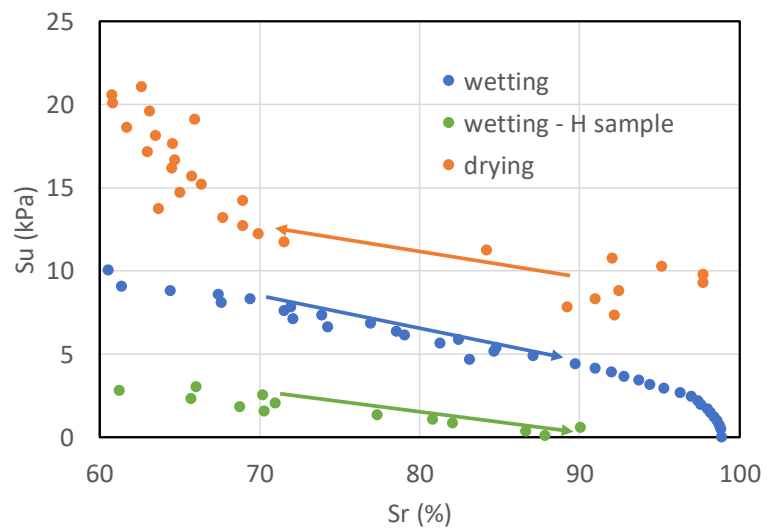

Fig. 3. Suction and saturation degree relations of $A$ and $H$ samples at laboratory condition.

\subsection{Test conditions}

A series of triaxial compression tests was carried out for $\mathrm{A}$ and $\mathrm{H}$ samples. The triaxial compression specimen was prepared by wet tamping method so that the condition would become predetermined density and water content. The size of the specimen was approximately $50 \mathrm{~mm}$ in diameter and $100 \mathrm{~mm}$ in height. Three kinds of test were carried out. 
The unsaturated tests were conducted using unsaturated triaxial compression test apparatus. The apparatus consisted of the bottom pedestal with a ceramic disk of $\mathrm{AEV}=200 \mathrm{kPa}$. The hydrophobic resin filter was installed on the top end of specimen. Besides, a top-pedestal embedded pore-air-pressure transducer was mounted. And in order to represent the undrained pore air condition, the opening-and-closing valve was integrated into the top pedestal. After setting the specimen on the pedestals in triaxial cell, initial suction condition was maintained under $20 \mathrm{MPa}$ of confining pressure for 1 day. Then, a predetermined net confining and pore air pressures were also applied as consolidation process for 1 day so that it was controlled in predetermined suction condition. The pore water pressure was kept to atmospheric condition.

In triaxial compression process, three drainage conditions to the unsaturated specimens were represented. First is pore-air drained / pore-water drained conditions so called as drained air and water (DADW) condition. Second is pore-air undrained / pore-water undrained conditions so called as undrained air and water (UAUW) condition. Third is pore-air drained / pore-water undrained condition, so called as drained air and undrained water (DAUW) condition.

The partially and fully saturated tests were conducted using ordinarily triaxial compression test apparatus. After setting the specimen on the pedestals in triaxial cell, initial confining pressure of $20 \mathrm{kPa}$ was applied. The partially saturated specimens were made by permeating of de-aired water only. The fully saturated specimen was prepared by permeating of $\mathrm{CO}_{2}$ and de-aired water and applying of back pressure of $200 \mathrm{kPa}$. The consolidation process was conducting under the confining pressure of $50 \mathrm{kPa}$ for 12 hours. The partially and fully saturated specimen was sheared under undrained condition.

Table 2 and 3 show the list of test condition and results which are the saturation degree at the end of consolidation, deviatoric stress at peak and pore water pressure at peak. The all specimens were compressed by a constant displacement rate of $0.05 \% / \mathrm{min}$ after consolidation process.

\section{Test results}

\subsection{Effects of drainage}

Fig. 4 indicates the influence of the drainage condition of A sample. The triaxial compression strength become larger in order of UAUW, DAUW, and DADW conditions. The volume dilation tendency is remarkable in this order. Figure (b) shows the results of pore air and pore water pressure. The results of UAUW and DAUW conditions show the gradual increase of pore water pressure. The pore air pressure of UAUW is decreasing, after temporal increasing. This means that the net stress is finally increasing. But the suction become smaller during shear. That is, the triaxial compression strength becomes higher as the suction is larger.
Table 2. Test conditions and results for A sample.

\begin{tabular}{|l|c|c|c|c|c|c|}
\hline Test & $\begin{array}{c}\text { Drainage } \\
\text { type }\end{array}$ & $\begin{array}{c}\text { Net } \\
\text { stress } \\
(\mathrm{kPa})\end{array}$ & $\begin{array}{c}\mathrm{u}_{\mathrm{a}} \\
(\mathrm{kPa})\end{array}$ & $\begin{array}{c}\mathrm{Sr} \\
(\%)\end{array}$ & $\begin{array}{c}\mathrm{q}_{\mathrm{max}} \\
(\mathrm{kPa})\end{array}$ & $\begin{array}{c}\mathrm{u}_{\mathrm{w}} \\
(\mathrm{kPa})\end{array}$ \\
\hline $\begin{array}{c}\text { Unsatu- } \\
\text { rated }\end{array}$ & $\begin{array}{c}\text { Drained air and } \\
\text { water (DADW) }\end{array}$ & 50 & 15 & 81.7 & 222.5 & 0.0 \\
\hline $\begin{array}{c}\text { Unsatu- } \\
\text { rated }\end{array}$ & $\begin{array}{c}\text { Undrained air and } \\
\text { water (UAUW) }\end{array}$ & 50 & 15 & 82.8 & 215.7 & 5.1 \\
\hline $\begin{array}{c}\text { Unsatu- } \\
\text { rated }\end{array}$ & $\begin{array}{c}\text { Drained air and } \\
\text { undrained water } \\
\text { (DAUW-15) }\end{array}$ & 50 & 15 & 78.5 & 222.9 & 4.0 \\
\hline $\begin{array}{c}\text { Unsatu- } \\
\text { rated }\end{array}$ & $\begin{array}{c}\text { Drained air and } \\
\text { undrained water } \\
\text { (DAUW-30) }\end{array}$ & 50 & 30 & 68.7 & 236.2 & 5.0 \\
\hline $\begin{array}{c}\text { Partially } \\
\text { satu- } \\
\text { ration }\end{array}$ & $\begin{array}{c}\text { Undrained water } \\
\text { (UW-p) }\end{array}$ & 50 & 0 & 95.8 & 196.9 & 0.9 \\
\hline $\begin{array}{c}\text { Partially } \\
\text { satu- } \\
\text { rated }\end{array}$ & $\begin{array}{c}\text { Undrained water } \\
\text { (UW-p) }\end{array}$ & 50 & 0 & 100 & 153.6 & 2.4 \\
\hline
\end{tabular}

Table 3. Test conditions and results for $\mathrm{H}$ sample.

\begin{tabular}{|c|c|c|c|c|c|c|}
\hline Test & Drainage & $\begin{array}{c}\mathrm{Net} \\
\text { stress } \\
(\mathrm{kPa})\end{array}$ & $\begin{array}{c}\mathrm{u}_{\mathrm{a}} \\
(\mathrm{kPa}\end{array}$ & $\begin{array}{c}\mathrm{Sr} \\
(\%)\end{array}$ & $\begin{array}{c}\mathrm{q}_{\max } \\
(\mathrm{kPa})\end{array}$ & $\begin{array}{c}\mathrm{u}_{\mathrm{w}} \\
(\mathrm{kPa})\end{array}$ \\
\hline $\begin{array}{c}\text { Unsatu- } \\
\text { rated }\end{array}$ & $\begin{array}{c}\text { Drained air and } \\
\text { undrained water } \\
\text { (DAUW-10) }\end{array}$ & 50 & 10 & 84.8 & 164.2 & 6.8 \\
\hline $\begin{array}{c}\text { Unsatu- } \\
\text { rated }\end{array}$ & $\begin{array}{c}\text { Drained air and } \\
\text { undrained water } \\
\text { (DAUW-5) }\end{array}$ & 50 & 5 & 90.3 & 181.7 & 8.8 \\
\hline $\begin{array}{c}\text { Partially } \\
\text { satu- } \\
\text { ration }\end{array}$ & $\begin{array}{c}\text { Undrained water } \\
\text { (UW-p) }\end{array}$ & 50 & 0 & 93.1 & 128.7 & 12.9 \\
\hline $\begin{array}{c}\text { Fully } \\
\text { satu- } \\
\text { rated }\end{array}$ & $\begin{array}{c}\text { Undrained water } \\
\text { (UW-f) }\end{array}$ & 50 & 0 & 100 & 41.5 & 33.5 \\
\hline
\end{tabular}

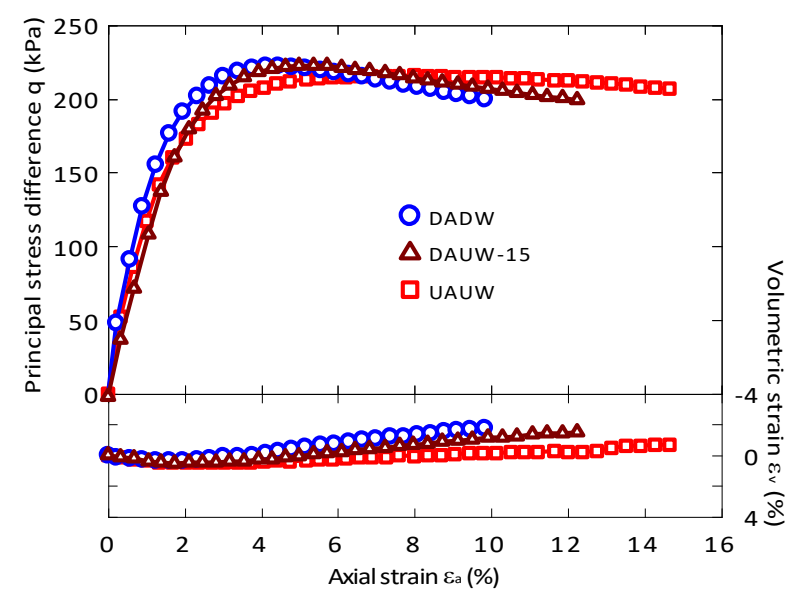

(a) Stress - strain behaviour 


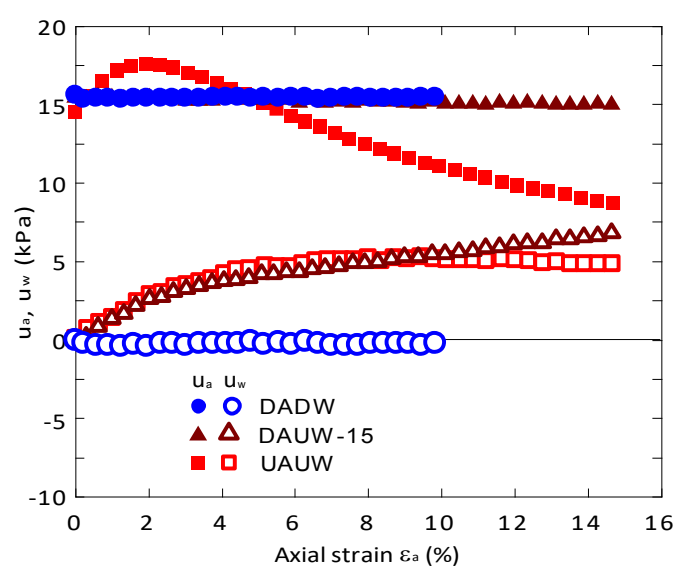

(b) Variation of pore water and air pressures

Fig. 4. Effect of drainage on unsaturated triaxial behaviour for A sample.

\subsection{Effects of saturation}

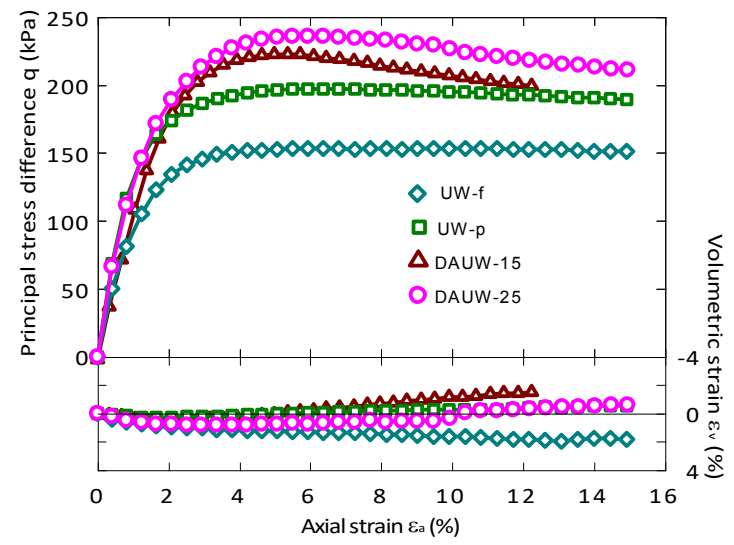

(a) Stress - strain behaviour

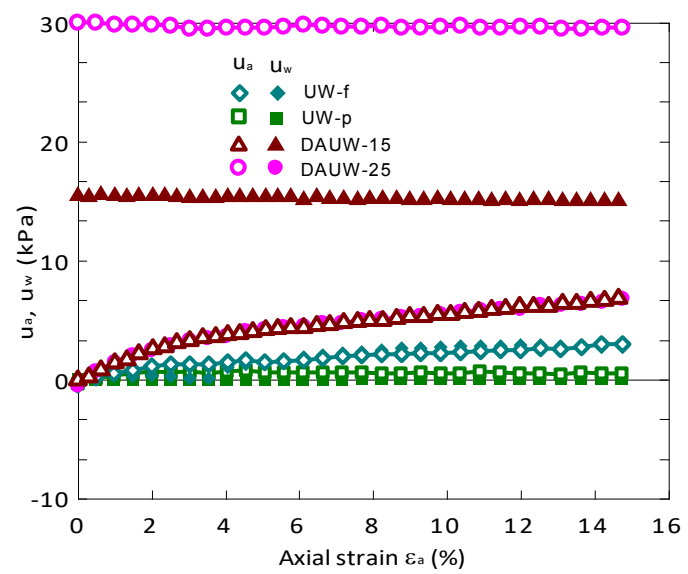

(b) Variation of pore water and air pressures

Fig. 5. Effect of saturation on undrained triaxial compression behaviour for A sample.

Fig. 5 shows the influence of saturation on the undrained triaxial compression behaviour of A sample. The undrained strength is higher in order of UW-f, UW-p, DAUW-15 and DAUW-30. As the degree of saturation becomes lower, the undrained strength increases which is known as general tendency. The more volume dilation occurred during triaxial compression as the degree of saturation becomes lower. On the other hand, positive excess pore water pressure occurred.

Fig. 6 shows the influence of saturation on the triaxial compression behaviour of $\mathrm{H}$ sample. As the initial saturation degree decreases, the volume contraction is larger. The contractive tendency of $\mathrm{H}$ sample brought the interesting opposite result as the dilative tendency of A sample. Then, the specimen with higher saturation indicated larger excess pore water pressure, and mobilised lower undrained strength.

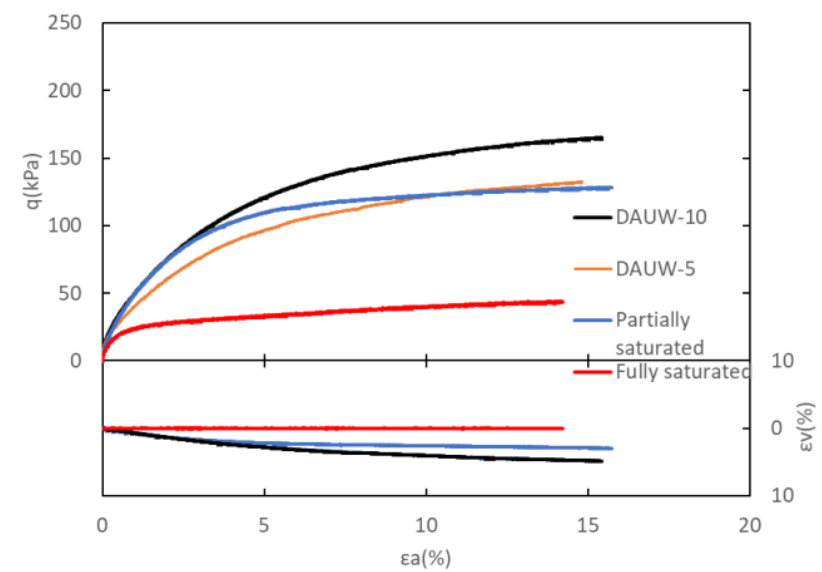

(a) Stress - strain behaviour

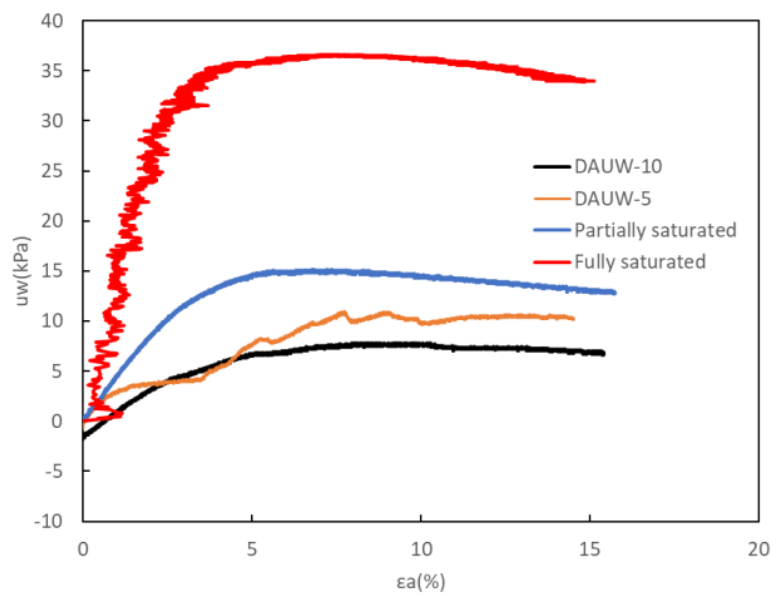

(b) Variation of pore water pressures

Fig. 6. Effect of saturation on undrained triaxial compression behaviour for $\mathrm{H}$ sample.

We need to know the influence of pore pressure coefficient on the undrained shear strength from partially to fully saturation. Fig. 7 shows the relationship between $B$ value and saturation degree of two samples theoretically. The theoretical equation was described by Kamata, et al., 2009 [1] as written in below.

$$
S_{r}=\frac{C_{a}-\frac{C_{b}(1-B)}{n B^{2}}}{C_{a}-C_{w}}
$$

where $\mathrm{C}_{\mathrm{a}}$ and $\mathrm{C}_{\mathrm{w}}$ are the compressibility of air and water. $\mathrm{C}_{\mathrm{b}}$ and $\mathrm{n}$ is the compressibility and the porosity of soil. 
In the case of A sample with $93 \%$ of degree of saturation, $B$ value was 0.3 . For $H$ sample, the $B$ value was 0.45 . The lower B value for A sample originated by higher compressibility. This is that A sample has the influence of $B$ value more than $H$ sample so that the excess pore water pressure of A sample was suppressed more.

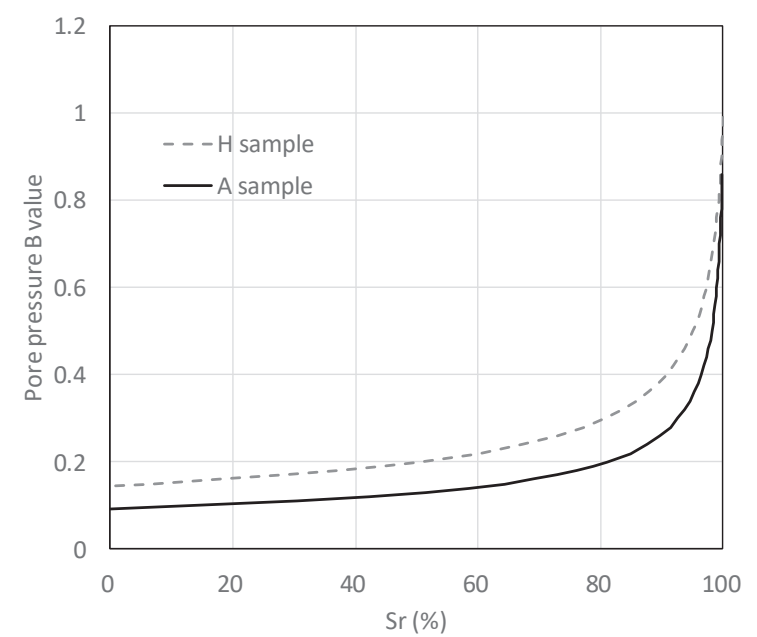

Fig. 7. Pore pressure $B$ value and saturation degree for $A$ and $H$ samples.

Fig. 8 shows the peak deviatoric stress and pore water pressure at peak plotted against the suction at peak for unsaturated specimens of A sample. The figure shows the relationship between suction and residual deviatoric stress at the end of tests. The peak stress of the unsaturated specimens is strongly dependent on the suction state. The dependence does not have influence of drainage conditions. Moreover, the residual strength does not have an effect of suction clearly.

In order to examine the shear strength under porewater undrained condition of the compacted soil specimen, the shear strength of A sample obtained DAUW-30, DAUW-15 and UW-p were plotted against saturation degree at consolidation as shown in Fig. 9. The undrained strength of the specimen decreases linearly as the saturation degree increases. The specimen of $\mathrm{Sr}=100 \%$ shows the lower strength than the liner relation and is falling by about $40 \mathrm{kPa}$.

Fig. 10 shows the results of $H$ sample. The shear strength of the two unsaturated specimens were 164 and $182 \mathrm{kPa}$. The undrained strength of partially saturated specimen was $129 \mathrm{kPa}$. By changing from the unsaturated to partially saturated condition, there was the decrease of $35 \mathrm{kPa}$ of undrained strength. It is interesting that the undrained strength of fully saturated condition is $42 \mathrm{kPa}$. So, $87 \mathrm{kPa}$ of decrease of strength is observed comparing with partially saturated condition. As the result, the strength reduction from partially saturation to fully saturation of $\mathrm{H}$ sample seems to be more remarkable than the reduction of A sample as shown in Fig.9. It can be said that the strength reduction from unsaturated to saturated conditions become drastic of volume contraction material.

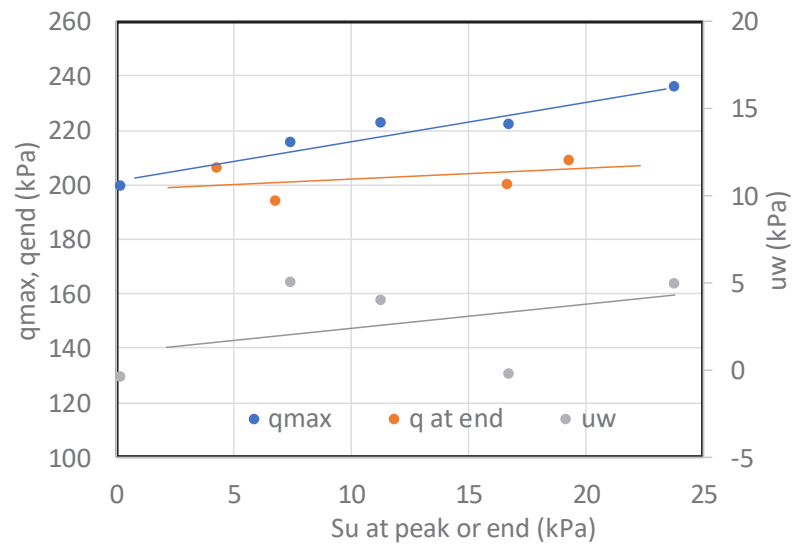

Fig. 8. Peak deviatoric stress and suction for unsaturated tests of A sample.

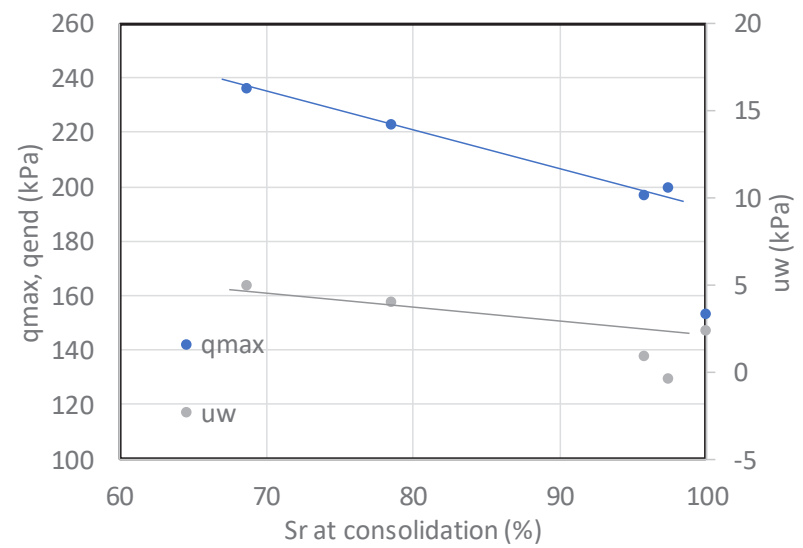

Fig. 9. Shear strength under pore-water undrained condition of the compacted A sample.

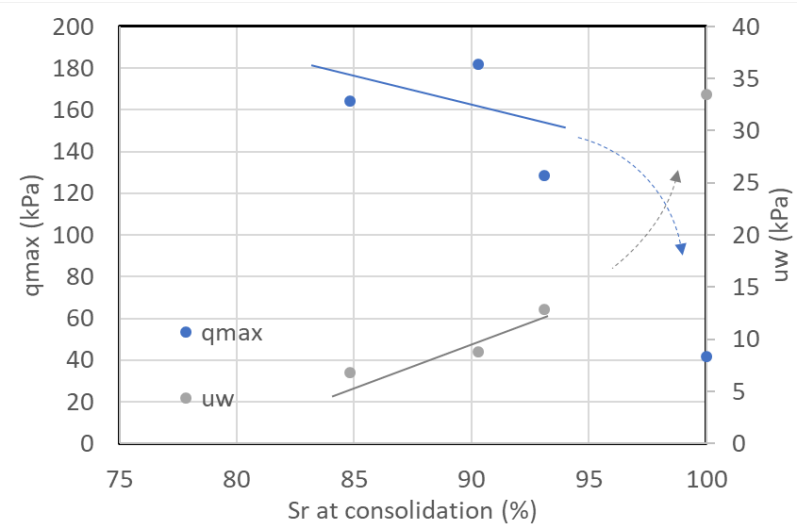

Fig. 10. Comparison between unsaturated (DAUW) and saturated undrained strength for $\mathrm{H}$ sample.

\section{Conclusions}

From collapse events of expressway embankment, in order to raise the quality of evaluation on stability, a series of triaxial compression tests was carried out for the compacted materials sampled from embankments. The strength of unsaturated condition had strong effects of suction regardless of drainage condition. Moreover, it was shown that shear strength under pore-water undrained condition had the effects of saturation degree. The undrained strength of compacted material decreased with increase in the degree of saturation. Especially, the strength decreased from partially saturated condition to 
fully saturated condition was remarkable. The decrease of the materials with volume contractive behaviour was appeared clearly. It can be concluded that the embankment of such contractive material was reinforced or improved.

\section{References}

1. Kamata, T., Tsukamoto, Y., and Ishihara, K., Undrained shear strength of partially saturated sand in triaxial tests, Bulletin of the New Zealand Society for Earthquake Engineering, 42, 1, 57-62 (2009).

2. Okamura, M. and Soga, Y., Effects of pore fluid compressibility on liquefaction resistance of partially saturated sand, Soils and Foundations, 46, 5, 695-700 (2006).

3. Tsukamoto, Y., Kawabe, S., Matsumoto, J., Hagiwara, S., Cyclic resistance of two unsaturated silty sands against soil liquefaction, Soils and Foundations, 54, 6, 1094-1103 (2014).

4. Murata, H, Takekuni, K. and Nakata, Y., Slope failure of embankment in Sanyo expressway due to passage of typhoon $\mathbf{1 4}$ in 2005, Soils and Foundations, Vol.49, No.5, pp.797-806 (2009).

5. Unno, T., Kazama, M., Uzuoka, R., and Sento, N., Liquefaction of unsaturated sand considering the pore air pressure and volume compressibility of the soil particle skeleton. Soils and Foundations, 48, 1 87-89 (2008).

6. Vanapalli, S. K., and Fredlund, D. G., Interpretaion of undrained shear strength of unsaturated soils in terms of stress state variables, Symp. on Unsaturated Soils (1997). 